\title{
Association of quantitative trait loci for plant height with major dwarfing genes in rice
}

\author{
NING HUANG* $\dagger$, BRIGITTE COURTOIS $\dagger+$, GURDEV S. KHUSH $\dagger$, HONGXUAN LIN $\dagger \S$, \\ GUOLIANG WANG $\dagger \pi$, PING WU†, \& KANGLE ZHENG \\ $\dagger$ International Rice Research Institute, PO Box 933, 1099 Manila, Philippines, $\ddagger$ Centre de Cooperation Internationale \\ en Recherche Agronomique pour le Development, Montpellier, France and §China National Rice Research Institute, \\ Hangzhou, China.
}

\begin{abstract}
Quantitative trait loci (QTLs) for plant height in rice were mapped on to RFLP maps in five populations, whose sizes varied from 135 to 250 . A total of 23 QTLs were located in all 12 rice chromosomes, and eight of these QTLs were shared by at least two populations. The positions of the 23 mapped QTLs were compared to the positions of 13 major dwarfing or semi-dwarfing genes previously linked to RFLP markers. Results indicated that all 13 dwarfing or semidwarfing genes were in close proximity to the QTLs, providing evidence to support the hypothesis that QTLs and major genes were different alleles of the same loci.
\end{abstract}

Keywords: molecular markers, Oryza sativa, QTLs, RFLP.

\section{Introduction}

Recently, DNA markers such as restriction fragment length polymorphisms (RFLP) and specific amplicon polymorphisms (SAP) have provided hundreds of new markers which can be readily mapped in a single population. The rapid development of these DNA markers has resulted in the construction of three independent molecular maps in rice (Saito et al., 1991; Causse et al., 1994; Kurata et al., 1994). These maps have been used to locate a series of major genes governing resistance to bacterial blight (Ronald et al., 1992; Yoshimura et al., 1992; Zhang et al., 1994), blast (Yu, 1991), brown plant hopper (Ishii et al., 1994) and gall midge (Williams et al., 1994) and genes for morphological characters such as plant height (Yu, 1991; Ideta et al., 1992; Kishimoto et al., 1993; Abenes et al., 1994; Liang et al., 1994).

The rice RFLP marker maps also permit the mapping of quantitative trait loci (QTLs). Wang et al. (1994) identified 10 QTLs which contributed to partial blast resistance by RFLP analysis of about 300 recombinant inbred lines derived from an

\footnotetext{
*Correspondence.

ICurrent address: Department of Plant Pathology, University of California, Davis, CA 95616, U.S.A.

††Current address: Department of Soil Sciences and Plant Nutrition, Zhejiang Agricultural University, Hangzhou, China.
}

indica/japonica cross. Taking advantage of the available RFLP data, Champoux et al. (1995) located genes associated with root morphology and drought avoidance in the same population. RFLP analysis has also been used to map genes for associated nitrogen fixation and genes whose interaction conditions the spikelet fertility in an $F_{2}$ population of an indica/japonica cross (Wu et al., 1995a,b).

Some of the QTLs identified for partial resistance to blast are associated with major genes although it remains unclear if the QTLs and major genes are different alleles of the same loci or if they are closely linked (Wang et al., 1994). Beavis et al. (1991) observed a similar situation with plant height in four maize populations. They found that QTLs for plant height were associated with 13 of the 18 major genes known to affect plant height. This conclusion was based on the approximate alignment of the RFLP map and the conventional marker map. It was felt that the association between quantitative and qualitative genes could be more accurately examined if the major genes were mapped relative to the RFLP markers (Beavis et al., 1991). Both studies seem to support the hypothesis that the major and minor genes are different alleles of the same loci (Robertson, 1985).

In this paper, we report the identification of QTLs for plant height in five rice populations. We then compare these QTLs with the major gene loci which have been mapped relative to RFLP markers. We 
found a strong association between QTLs for plant height and major dwarfing genes in rice.

\section{Materials and methods}

\section{Populations}

The five populations used in this study are listed in Table 1 and were derived from either indica/japonica crosses (CO39/Moroberekan, IR64/Azucena, Palawan/IR42) or indica/indica crosses (Tesanai2/ $\mathrm{CB}$, Waiyin/CB). Details of population development have been previously described (Huang et al., 1994; Wang et al., 1994; Wu et al., 1995a; Lin et al., 1996). Except for IR42 and IR64 which carry the semidwarfing gene $s d-1$, it is not clear what major genes for plant height are carried by other parental lines.

\section{RFLP analysis}

Procedures for DNA extraction, restriction digestion, gel electrophoresis, Southern transfer and DNA/DNA hybridization followed the standard techniques (Ausubel et al., 1993). After a parental polymorphism survey, polymorphic RFLP markers (those coded as RG, RZ and CDO were provided by S. D. Tanksley, Cornell University, U. S. A. and those coded as Npb were provided by A. Saito, Tsukuba, Japan) covering all 12 rice chromosomes were scored for each population. The number of polymorphic markers scored in each population is given in Table 1. These markers were used to construct linkage maps using the computer program MAPMAKER (Lander et al., 1987) with map distances estimated by the Kosambi function in the program.

\section{Plant height}

Plant heights of the parents and their progenies were recorded. According to the Standard Evaluation System for Rice (IRRI, 1988) the definition of

Table 1 Rice populations used in mapping QTLs for plant height

\begin{tabular}{lccc}
\hline Crosses & $\begin{array}{c}\text { Population } \\
\text { size }\end{array}$ & $\begin{array}{c}\text { No. markers } \\
\text { scored }\end{array}$ & $\begin{array}{c}\text { Type of } \\
\text { population }\end{array}$ \\
\hline CO39/Moroberekan & 230 & 147 & RIL \\
IR64/Azucena & 135 & 135 & DHL \\
Palawan/IR42 & 231 & 104 & $\mathrm{~F}_{2}$ \\
Tesanai2/CB & 171 & 93 & $\mathrm{~F}_{2}$ \\
Waiyin/CB & 171 & 101 & $\mathrm{~F}_{2}$ \\
\hline
\end{tabular}

RIL, recombinant inbred lines; DHL, doubled haploid lines.

(C) The Genetical Society of Great Britain, Heredity, 77, 130-137. the plant height in this study is the distance in $\mathrm{cm}$ from the soil surface to the tip of the tallest panicle at maturity (awns excluded). Two replicated trials were conducted for recombinant inbred lines (RILs) and doubled haploid lines (DHLs) whereas there was no replication in each of the $\mathrm{F}_{2}$ populations. The individual plot consisted of three $5 \mathrm{~m}$ long rows, with $30 \mathrm{~cm}$ spacing between the rows and $25 \mathrm{~cm}$ between plants. To avoid border effects, 10 plants in the middle rows of each line were scored for plant height and the average of 10 plants in each replication was used for QTL analysis. Three populations (CO39/Moroberekan, IR64/Azucena, Palawan/IR42) were grown at the International Rice Research Institute, Philippines and the other two populations (Tesanai2/CB, Waiyin/CB) were grown at the China National Rice Research Institute, Hangzhou, China. Standard field management was practiced.

\section{Statistical analysis}

Two standard methods for QTL detection were used. MAPMAKER/OTL (Lander \& Botstein, 1989) and one-way ANOVA were performed using individual measurements for data derived from $F_{2}$ populations or the overall means of each line from the recombinant inbred population or the doubled haploid population. The results of these two procedures were similar. One-way ANOVA with replicated data was also performed for the doubled haploid population. The results were generally the same as those from ANOVA with overall means although giving slightly higher sensitivity in detecting QTLs of minor effect as reported by Stuber et al. (1992). The threshold for declaring a QTL for plant height was $P<0.01$ for all populations except for the population derived from CO39/Moroberekan. Here, we used $P<0.001$ to declare a QTL as recommended in the original mapping for rice blast resistance because the population is strongly biased toward the indica parent, CO39 (Wang et al., 1994).

\section{Comparison of QTLs mapped in the five populations}

To determine the total number of QTLs identified, we pooled the QTLs identified from each of the five populations studied. Although the types of populations used were different (DHLs, RILs and $\mathrm{F}_{2} \mathrm{~s}$ ), the type of RFLP markers used was the same (Causse et al., 1994) so the map locations of the QTLs could be readily compared. The RFLP map developed from DHLs (Huang et al., 1994) was used as a basic framework map because it is used by many other 
scientists to map QTLs. Using this as the basic framework map will facilitate QTL comparisons in the future.

Two strategies were used to pool the QTLs. They were located directly on the map if the linked markers were already on the map. For example, six QTLs in the CO39/Moroberekan population were linked to RFLP markers, namely RG331, RG104, RG351, RG257, RG103 and RG574 (Table 4). These markers were in the framework map, so the QTLs were located on the map directly. When the linked RFLP markers were not in the framework map, the map of Causse et al. (1994) was used to bridge all the RFLP markers. In this way, all QTLs mapped in the five populations were placed in one map (Fig. 1). Their relative positions are covered by the lengths of bars on the map.

\section{Positioning of dwarfing or semi-dwarfing genes onto the RFLP map}

A total of 13 dwarfing or semi-dwarfing genes have been previously linked to RFLP markers directly or indirectly (Table 3). Upon positioning these genes on the framework map, they can be divided into three groups. The first group of mutants was those reported to be linked to RFLP markers already on the framework map. This includes mutants $d-5$ and $d-27$ which were then placed on the map directly.

The second group of mutant genes was those linked to RFLP markers which were not on the RFLP framework map. This includes mutant genes $s d-1, d-10, d-30, d-11, d-33, d-18$ and $s d g$. To place these genes on the framework map, we first placed them on the map of Causse et al. (1994) and then

Table 2 Phenotype of plant height in five populations of rice

\begin{tabular}{lcrrrr}
\hline Population & $\begin{array}{c}\text { Female } \\
\text { parent }\end{array}$ & $\begin{array}{c}\text { Male } \\
\text { parent }\end{array}$ & $\begin{array}{c}\text { Population } \\
\text { mean } \pm \text { SD }\end{array}$ & Skewness & Kurtosis \\
\hline CO39/Moroberekan & 128 & \multicolumn{1}{c}{60} & $88.4 \pm 18.9$ & 0.48 & -0.76 \\
IR64/Azucena & 73.5 & 141.5 & $103.2 \pm 21.7$ & 0.20 & 0.54 \\
Palawan/IR42 & 164.3 & 91.1 & $123.7 \pm 21.1$ & 0.15 & 0.09 \\
Tesanai 2/CB & 103.3 & 66.9 & $96.0 \pm 16.2$ & 0.15 & 0.74 \\
Waiyin/CB & 108.9 & 66.9 & $108.4 \pm 20.3$ & -0.26 & 0.02 \\
\hline
\end{tabular}

Table 3 Qualitative genetic loci for plant height in rice and the linked markers

\begin{tabular}{|c|c|c|c|}
\hline Gene & $\begin{array}{c}\text { Chromosome } \\
\text { no. }\end{array}$ & $\begin{array}{l}\text { Linked } \\
\text { marker }\end{array}$ & Reference \\
\hline$d-10$ & 1 & RG462 & Yu (1991) \\
\hline$s d-1$ & 1 & RG220 & Cho et al. (1994) \\
\hline$d-18$ & 1 & Npb96 & Ideta et al. (1992) \\
\hline & & RZ288 & Xiao et al. (1992) \\
\hline$d-5$ & 2 & RG256 & Yu (1991) \\
\hline$d-30$ & 2 & $\begin{array}{l}\text { Npb243 } \\
\text { RG171 }\end{array}$ & $\begin{array}{l}\text { Saito et al. (1991) } \\
\text { Xiao et al. (1992) }\end{array}$ \\
\hline$d-32$ & 2 & $10 \%$ from $d-30$ & Kinoshita (1993) \\
\hline$d-56$ & 3 & $\begin{array}{l}\text { Linked to } \mathrm{Hg} \\
\text { Hg linked to RG348 }\end{array}$ & $\begin{array}{l}\text { Kinoshita (1993) } \\
\text { Yu (1991) }\end{array}$ \\
\hline$d-31$ & 4 & $\begin{array}{l}\text { Linked to Pr } \\
\text { Pr linked to RG63 }\end{array}$ & $\begin{array}{l}\text { Kinoshita (1993) } \\
\text { Yu (1991) }\end{array}$ \\
\hline$d-11$ & 4 & CDO456 & Yu (1991) \\
\hline$d-11$ & 4 & $\begin{array}{l}\text { Npb301 } \\
\text { RG163 }\end{array}$ & $\begin{array}{l}\text { Ideta et al. (1992) } \\
\text { Xiao et al. (1992) }\end{array}$ \\
\hline$s d g$ & 5 & RZ182 & Liang et al. (1994) \\
\hline$d-9$ & 6 & $\begin{array}{l}\text { Linked to Se-1 } \\
\text { Se-1 Linked to RG64 }\end{array}$ & $\begin{array}{l}\text { Kinoshita (1993) } \\
\text { MacKill et al. (1993) }\end{array}$ \\
\hline$d-27$ & 11 & RG103 & Abenes et al. (1994) \\
\hline$d-33$ & $\begin{array}{l}12 \\
12\end{array}$ & $\begin{array}{l}\text { Npb402 } \\
\text { R776 }\end{array}$ & Kishimoto et al. (1993) \\
\hline
\end{tabular}




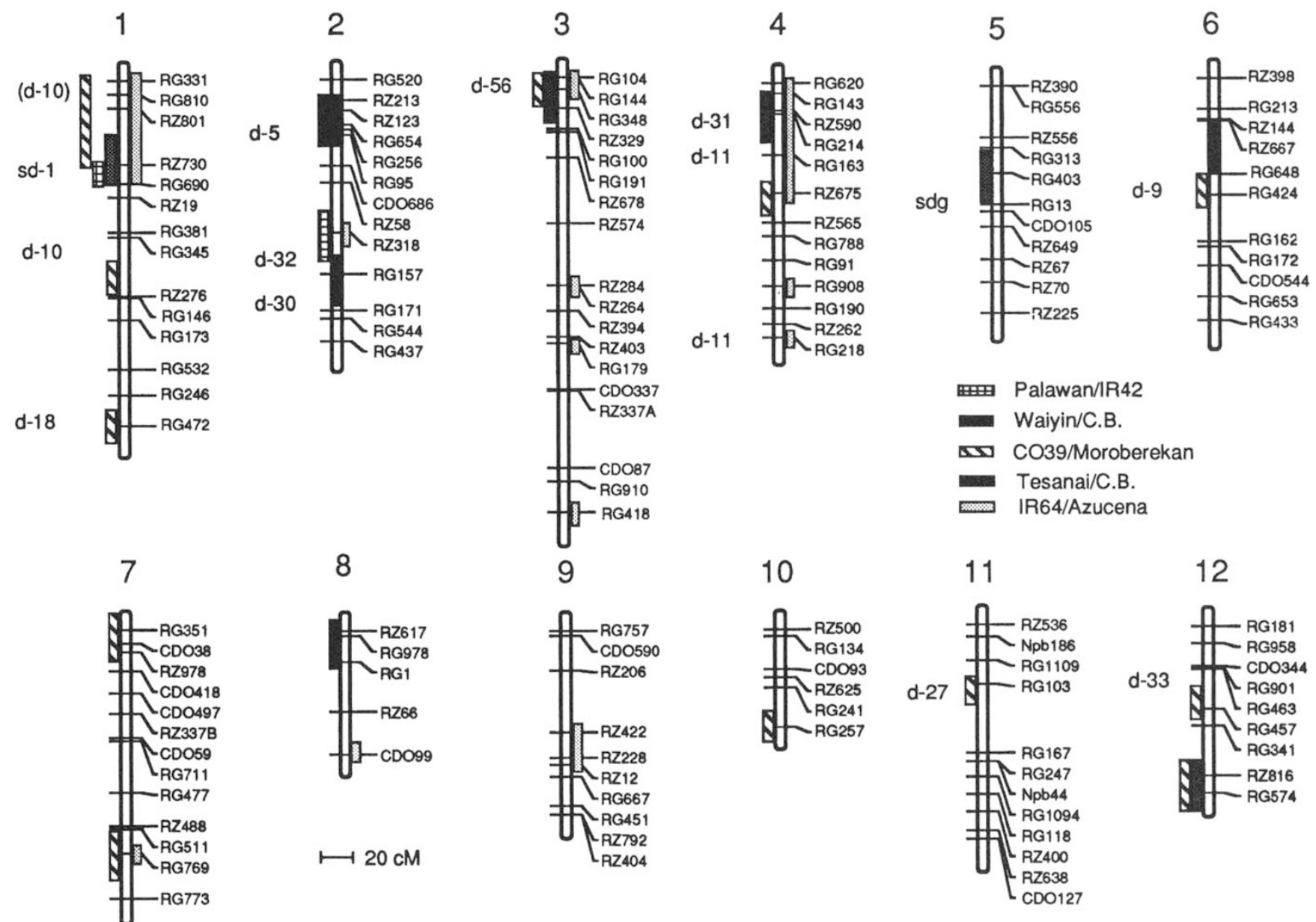

Fig. 1 RFLP map of rice showing QTLs for plant height in five populations and the major gene loci (Table 2). The most likely positions of the QTLs ( $P<0.01$ for all populations except $P<0.001$ for CO39/Moroberekan) on the map are indicated by bars of different patterns which represent the population used. The major dwarfing genes are placed on the map based on their direct or indirect linkage to RFLP markers (see Materials and methods for details).

related them to markers in Fig. 1. For example, mutant $d-10$ is closely linked to RG462 (Yu, 1991), which is in turn closely linked to RG345 (Causse et al., 1994), so $d-10$ is placed next to RG345 (Fig. 1). Mutant $d-30$ has been placed next to Npb243 (Saito et al., 1991). RFLP map integration showed that Npb243 and RG171 are very close to one another (Xiao et al., 1992), so $d-30$ is placed next to RG171. Mutants $d-11, d-33, d-18$ and $s d g$ in this group were positioned using the same approach. Two papers (Yu, 1991; Cho et al., 1994) were consulted to place sd-1 on the framework map. After considering the overall arrangement of RFLP markers and their linkage to $s d-1$, we agreed to place $s d-1$ near RG220 and between RG690 and RZ730 on the map of Causse et al. (1994).

The third group of mutants was those linked to other types of markers such as isozyme or morpho- logical markers. These markers have been shown to be linked to RFLP markers. This group includes mutants $d-32, d-56, d-31$ and $d-9$. To place these genes on to the framework map, we placed the mutant loci, linked markers and RFLPs on the map of Causse et al. (1994) and then positioned the mutants as in Fig. 1. In doing so, other available information was also taken into account. For example, $d-32$ is $15 \mathrm{cM}$ away from $d-30$ on chromosome 2 (Kinoshita, 1993). It has been shown that $d-30$ is linked to Npb243/RG171 (Saito et al., 1991; Xiao et al., 1992). By reference to the integration of RFLP and conventional genetic maps (Kishimoto et al., 1993), $d-32$ is believed to be located near RG157 instead of RG437 (Fig. 1). The same approach was used to position the other three mutants (Fig. 1).

We have placed two mutant genes, $d-10$ and $d-11$, in two different locations (Fig. 1). Based on the map 
alignment, $d-10$ should be at the end of chromosome 1 but $\mathrm{Yu}$ (1991) reported $d-10$ to be linked to RG462 which is located in the middle of chromosome 1. Two different groups (Yu, 1991; Ideta et al., 1992) have mapped $d-11$ with RFLP markers on chromosome 4 but at two different locations (Fig. 1).

\section{Results}

\section{Identification of QTLs for plant height in the five populations}

To identify QTLs for plant height, five populations were used (Table 1). Table 2 shows the phenotypic performance of plant height in all five populations. The difference in plant height between the two parents is significant. The means of the populations are generally between the two parents except in Waiyin/CB where the mean of the population is about the same as that of Waiyin. The values of skewness and kurtosis are all less than 1 indicating normal distributions of plant height in these five populations. Both single factor and interval analyses were performed to identify QTLs affecting plant height. The same curves of LOD scores and $F$-values were observed and an example is given in Fig. 2 .

A total of 12 QTLs for plant height were identified in the IR64/Azucena population (Fig. 1). These QTLs were located on seven different chromosomes. The effect of the QTLs varied. The one on chromosome 1 had the largest effect among all QTLs in the IR64/Azucena population, controlling 64 per cent of the phenotypic variation. A total of 12 QTLs for plant height were identified from the CO39/Mor- oberekan population (Fig. 1, Table 4). These QTLs were distributed over eight chromosomes. Three QTLs were located on chromosome 1 and two were located on chromosomes 7 and 12 . A relatively small number of QTLs for plant height were identified from the three other $\mathrm{F}_{2}$ populations. Two QTLs were detected in the Palawan/IR42 population and three were located in the Waiyin/CB population. Seven from the Tesanai $2 / C B$ population were located on seven rice chromosomes (Fig. 1).

The pooling of QTLs for plant height (see Materials and methods) permits the comparison of the QTLs identified in each population (Fig. 1). Eight QTLs were shared by at least two populations but

Table 4 QTLs identified from the CO39/Moroberekan rice population

\begin{tabular}{lccc}
\hline $\begin{array}{l}\text { Markers } \\
\text { linked } \\
\text { to QTLs }\end{array}$ & $\begin{array}{c}\text { Chromosome } \\
\text { no. }\end{array}$ & $F$-value & $P$-value \\
\hline RG331 & 1 & 25.5310 & 0.0000010 \\
RZ744 & 1 & 22.0785 & 0.0000051 \\
RG612 & 1 & 16.6020 & 0.0000691 \\
RG104 & 3 & 17.6810 & 0.0000402 \\
RG864 & 4 & 12.1743 & 0.0006048 \\
RG64 & 6 & 33.6397 & 0.0000000 \\
RG351 & 7 & 30.7234 & 0.0000001 \\
RG528 & 7 & 14.2698 & 0.0002130 \\
RG257 & 10 & 24.2956 & 0.0000018 \\
RG103 & 11 & 18.7966 & 0.0000236 \\
RG869 & 12 & 11.9934 & 0.0006603 \\
RG574 & 12 & 13.1730 & 0.0003684 \\
\hline
\end{tabular}

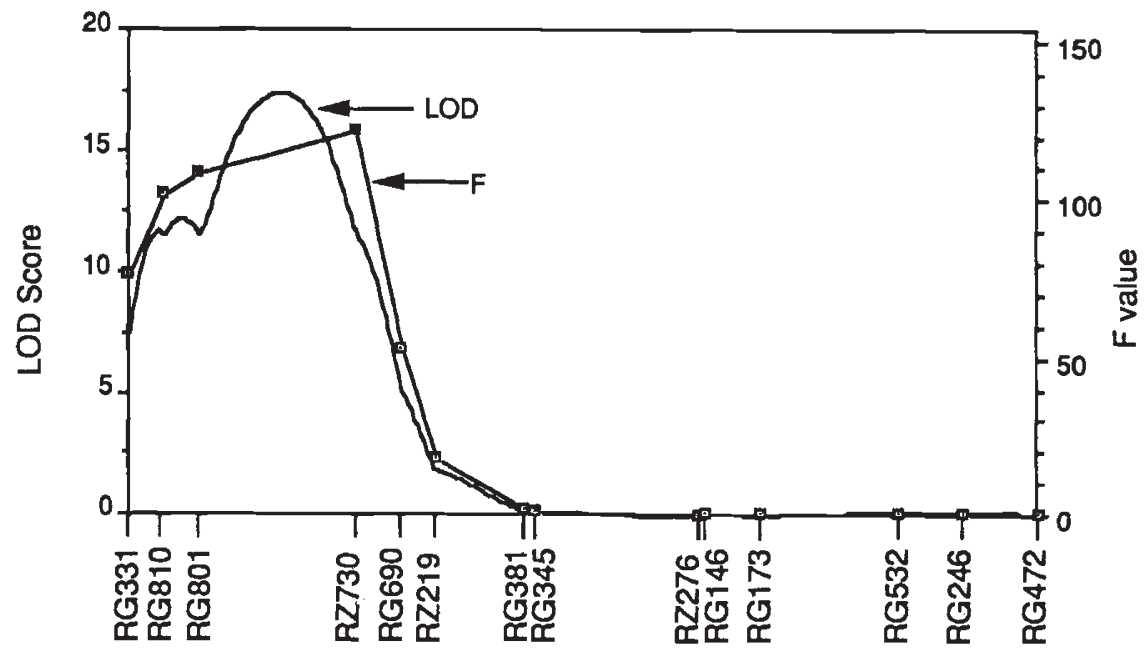

Linkage map of Chromosome 1 (IR64/Azucena)
Fig. 2 LOD plot and $F$-value curve on a linkage map of chromosome 1 in the IR64/Azucena population. The LOD plot is generated by MAPMAKER/QTL and $F$-values are derived from a one-way ANOVA for plant height. The QTL is located between RG690 and RG331, with the most likely position being near RZ730. 
no single QTL was shared in all five populations. Fifteen QTLs for plant height were present in only one of the five populations. The sharing of QTLs by two or more populations indicated that the genes residing at those loci were segregating in those populations. At least 23 QTLs for plant height were identified from all five populations distributed over all 12 rice chromosomes. The abundance of QTLs from five populations indicated that many loci in the rice genome influence plant height which is congruent with the large number of known mutants affecting plant height (Kinoshita, 1993).

\section{Association of a QTL for plant height and the semi- dwarfing gene sd-1}

An alignment with results obtained by Yu (1991) and Cho et al. (1994) showed that a QTL identified in chromosome 1 of the $\mathrm{DH}$ population was in the same region as the semi-dwarfing gene $s d-1$. The pedigree of IR64 indicates that it carries the semidwarfing gene sd-1 (IRRI, 1975). It is possible that the QTL identified on chromosome 1 in the IR64/Azucena population is $s d-1$. As in IR64, IR42 is also a semi-dwarf variety carrying sd-1 (IRRI, 1975). Analysis by one-way ANOVA and MAPMAKER/ QTL on chromosome 1 showed that a strong QTL was near the RFLP marker, RZ730 (Fig. 1). The QTL identified on chromosome 1 is likely to be the qualitative semi-dwarfing gene $s d-1$.

The semi-dwarfing gene $s d-1$ is a recessive mutant. If the wild-type allele of the $s d-1$ locus also has an effect on plant height, it should be detectable if it is segregating in a population. We found that in two out of three populations a QTL is located in the area close to RZ730, supporting allelic association of mutant allele $s d-1$ and the QTL.

\section{Association of QTLs for plant height and other dwarf mutants}

In order to associate the QTLs for plant height with other dwarfing mutant genes, we need to have the major genes mapped relative to the RFLP markers. We have recently mapped a tillering dwarfing gene ( $d-27)$ and found it to be closely linked to the RFLP marker RG103 (Abenes et al., 1994) where a QTL was placed in this study (Fig. 1). Encouraged by this result, we compiled a list of dwarfing or semi-dwarfing genes which have been mapped to RFLP markers either directly or indirectly (Table 3 ). These genes were placed on to the framework map (see Materials and methods).
Based on the location of both QTLs for plant height and major dwarfing genes, it is evident that all dwarfing genes are located very close to QTLs (Fig. 1). There is not a single case where the dwarfing gene is not associated with a QTL. There must be an underlying reason for this high level of association between QTLs for plant height and major dwarfing genes. The best explanation is Robertson's (1985) hypothesis which states that quantitative and qualitative trait loci are the same.

\section{Discussion}

In this study, we have mapped at least 23 QTLs in five populations. Both permanent populations (RILs and DHLs) and standard $F_{2}$ populations were used for QTL mapping. Only a small number of QTLs were identified from the three $F_{2}$ populations. These QTLs tend to appear in other populations as well, indicating the validity of mapping QTLs for plant height in $F_{2}$ populations. Genotypically identical seeds can be produced from permanent populations and therefore replicated trials can be performed. Block effect, replication effect and random errors can be minimized or partitioned out so that the sensitivity of QTL detection can be increased. This may explain why more QTLs were mapped in both RILs and DHLs than in $F_{2}$ mapping populations. Other studies have also shown that in QTL mapping analysis, the use of permanent populations offers advantages over nonpermanent populations.

Among the QTLs identified in the five populations, eight were identified in at least two populations. Fifteen QTLs were detected only in one population. There are several possible explanations for these observations: (i) there is no variation between the two parents for some QTLs, so there was no segregation for those QTLs; (ii) lack of gene expression in some populations because of different genetic backgrounds; (iii) environmental effects which confound the expression of some QTLs, especially for $F_{2}$ populations where QTLs with very small effects cannot be detected without replicated trials.

Plant height in rice is generally considered to be controlled by both qualitative and quantitative genes. It is further assumed that qualitative genes play a major role whereas quantitative genes play a minor role. This assumption implies that qualitative and quantitative genes for plant height in rice are different genes. However, there is a very strong association between the map locations of both QTLs and major dwarfing genes, indicating that qualitative and quantitative genes may be different alleles at the 
same loci. Robertson (1985) suggested that qualitative genes are null or near-null alleles of quantitative loci. The results of the present study tend to support Robertson's hypothesis. The general alignment of the RFLP and conventional maps of maize has also shown that QTLs for plant height are associated with major dwarfing genes (Beavis et al., 1991).

This study deals with plant height. However, we assume that the observation that quantitative genes are alleles of qualitative loci may not apply just to plant height. Indeed, some major genes for blast resistance have been shown to be associated with minor resistance genes (QTLs) (Wang et al., 1994). Furthermore, we have observed that $\mathrm{Xa}-4$ behaves as a qualitative gene for resistance to some races of bacterial blight pathogen but as a quantitative gene to other races (R. Nelson \& N. Huang, unpublished data). It is possible that this observation of association between major and minor genes may apply to many other characters.

\section{Acknowledgements}

The authors would like to thank Tita Mew and Marescielle Mendoza for technical assistance and Yollie Aranguren for typing the manuscript.

\section{References}

ABENES, M. L. P., TABIEN, R. E., McCOUCH, S. R., 1KEDA, R., RONALD, P., KHUSH, G. S. AND HUANG, N. 1994. Orientation and integration of the classical and molecular genetic maps of chromosome 11 in rice. Euphytica, 76, $81-87$.

AUSUBEL, F. M., BRENT, R., KINGSTON, R. E., MOORE, D. D., SEIDMAN, J. G., SMith, J. A. AND STRuhl, K. 1993. Current Protocols in Molecular Biology. John Wiley and Sons, New York.

BEAVIS, W. D., GRANT, D., ALBERTSEN, M. AND FINCHER, R. 1991. Quantitative trait loci for plant height in four maize populations and their associations with qualitative genetic loci. Theor. Appl. Genet., 83, 141-145.

CAUSSE, M. A., Fulton, T. M., CHO, Y. G., AHN, S. N., CHUN. WONGSE, J., WU, K. 1994. Saturated molecular map of the rice genome based on an interspecific backcross population. Genetics, 138, 1251-1274.

CHAMPOUX, M. C., WANG, G., SARKARUNG, S., MACKILl, D. J., O'TOOLE, J. C., HUANG, N. AND MCCOUCH, S, R. 1995. Locating genes associated with root morphology and drought avoidance in rice via linkage to molecular markers. Theor. Appl. Genet., 90, 969--981.

CHO, Y. G., EUN, M. Y., McCOUCH, S. R. AND CHAE, Y. A. 1994. The semidwarf gene, sd-1, of rice (Oryza sativa L.). II. Molecular mapping and marker-assisted selection. Theor. Appl. Genet., 89, 54-59.
HUANG, N., McCOUCH, S., MEW, T., PARCO, A. AND GUIDEDONI, E. 1994. Development of an RFLP map from a doubled haploid population in rice. Rice Genet. Newsl., 11, 134-137.

IDETA, O., YOShIMURA, A., MATSUmoto, T., TSUnemATSU, H. AND 1WATA, N. 1992. Integration of conventional and RFLP linkage maps in rice. I. Chromosomes, 12,3 and 4. Rice Genet Newsl., 9, 128-129.

IRR1 1975. Parentage of IRRI crosses IRI-IR50,000. International Rice Research Institute, Manila, Philippines.

1RR1 1988. Standard evaluation system for rice. International Rice Research Institute, Manila, Philippines.

1SH11, T., BRAR, D. S., MULTANI, D. S., AND KHUSH, G. S. 1994. Molecular tagging of genes for brown planthopper resistance and earliness introgressed from Oryza australiensis into cultivated rice, $O$. sativa. Genome, 37, 217-221.

KINOSHITA, T. 1993. Report of the committee on gene symbolization, nomenclature and linkage groups. Rice Genet. Newsl., 10, 7-39.

KISHIMOTO, N., FOOLAD, M. R., SHIMOSAKA, E., MATSUURA, S. AND SAITO, A. 1993. Alignment of molecular and classical linkage maps of rice, Oryza sativa. Pl. Cell Rep., 12, 457-461.

KURATA, N., NAGAMURA, Y., TAMAMOTO, K., HARUSHIMA, Y., SUE, N., WU, J. ET AL. 1994. A 300 kilobase interval genetic map of rice including 883 expressed sequences. Nature Genetics, 8, 365-372.

LANDER, E. S. AND BOTSTEIN, D. 1989. Mapping Mendelian factors underlying quantitative traits using RFLP linkage maps. Genetics, 121,185-199.

LANDER, E. S., GREEN, P., ABRAHAMSON, J., BARLOW, A., DALY, M. J., LINCOLN, S. E. AND NEWBURG, L. 1987. MAPMAKER: An interactive computer package for constructing primary genetic linkage maps of experimental and natural populations. Genomics, 1, 174-181.

L1ANG, C. Z., GU, M. H., PAN, X. B., L1ANG, G. H. AND ZHU, L. H. 1994. RFLP tagging of a new semi-dwarfing gene in rice. Theor. Appl. Genet., 88, 898-900.

LIN, H., QIAN, H., ZHUANG, J., LU, J., MIN, S., XIONG, Z. ET $A L$. 1996. RFLP mapping of QTLs for yield and related characters in rice (Oryza sativa L.). Theor. Appl. Genet. (in press).

MACK1LL, D. J., SALAM, M. A., WANG, Z. Y. AND TANKSLEY, S. D. 1993. A major photoperiod-sensitivity gene tagged with RFLP and isozyme markers in rice. Theor. Appl. Genet., 85, 536-540.

ROBERTSON, D. S. 1985. A possible technique for isolating genic DNA for quantitative traits in plants. $J$. Theor. Biol., 117, 1-10.

RONALD, P. C., ALBANO, B., TAB1EN, R., ABENES, L., WU, K., MCCOUCH, S. R. AND TANKSLEY, S. D. 1992. Genetic and physical analysis of the rice bacterial blight disease resistance locus Xa21. Mol. Gen. Genet., 236, 113-120.

SAITO, A., YANO, M., KISHIMOTO, N., NAKAGAHRA, M., YOSH1MURA, A., SAITO, K. ET $A L$. 1991. Linkage map of restriction fragment length polymorphism loci in rice. Jap. J. Breeding, 41, 665-670.

STUBER, C. W., LINCOLN, S. E., WOLFF, D. W., HELENTJARIS,

(C) The Genetical Society of Great Britain, Heredity, 77, 130-137. 
T. AND LANDER, E. S. 1992. Identification of genetic factors contributing to heterosis in a hybrid from two elite maize inbred lines using molecular markers. Genetics, 132, 823-839.

WANG, G. L., MACKILL, D. J., BONMAN, J. M., McCOUCH, S. R., CHAMPOUX, M. AND NELSON, R. 1994. RFLP mapping of genes conferring complete and partial resistance to blast in a durably resistant rice cultivar. Genetics, 136, 1421-1434.

WILlIAMS, M. N. V., PANDE, N., NAIR, S., MOHAN, M. AND BENNETT, J. 1994. Restriction fragment length polymorphism analysis of polymerase chain reaction products amplified from mapped loci of rice (Oryza sativa L.) genomic DNA. Theor. Appl. Genet., 82, 489-498.

wU, P., ZHANG, G., HUANG, N. AND LADHA, J. K. 1995a. Non-allelic interaction conditioning spikelet sterility in an $\mathbf{F}_{2}$ population of indica/japonica cross in rice. Theor. Appl. Genet., 91, 825-829.

WU, P., ZHANG, G., LADHA, J. K., McCOUCH, S. R. AND HUANG, N. 1995b. Molecular-marker-facilitated investi- gation on the ability to stimulate $\mathrm{N}_{2}$ fixation in the Rhizosphere by irrigated rice plants. Theor. Appl. Genet., 91, 1177-1183.

XIAO, J., FULTON, T., McCOUCH, S. R., TANKSLEY, S. D., KISHIMOTO, N., OHSAWA, R. ET AL. 1992. Progress in integration of the molecular maps of rice. Rice Genet. Newsl., 9, 124-128.

YOSHIMURA, S., YOSHIMURA, A., SAITO, A., KISHIMOTO, N., KAWASE, M., YANO, M. ET AL. 1992. RFLP analysis of introgressed chromosomal segments in three nearisogenic lines of rice bacterial blight resistance genes, $X a-1, X a-3$ and $X a-4$. Jap. J. Genet., 67, 29-37.

YU, z. 1991. Molecular mapping of rice (Oryza sativa L.) genes via linkage to restriction fragment length polymorphism (RFLP) markers. Ph. D. Dissertation, Graduate School of Cornell University.

ZHANG, G., ANGELES, E. R., ABENES, M. L. P., KHUSH, G. S. AND HUANG, N. 1994. Molecular mapping of a bacterial blight resistance gene on chromosome 8 in rice. Rice Genet. Newsl., 11, 142-144. 